\title{
PERFORMANCE ALLOWANCES IN THE AL-'ADL PERSPECTIVE (STUDY AT THE INDONESIAN MINISTRY OF RELIGION, GOWA REGENCY)
}

\author{
Hikmah Pratiwi Hafid, Salma Said, Wahyuddin \\ Abdullah \\ STAI DDI Maros, UIN Alauddin Makassar \\ Jl. Rajawali Baniaga, Turikale, Taroada, Taroada, Kec. \\ Turikale, Kabupaten Maros, Sulawesi Selatan 90516 \\ Email: pratiwi.hikmah@yahoo.co.id; salmahsaid@uin- \\ alauddin.ac.id; tosirwahyu@yahoo.com
}

\begin{abstract}
This study discusses the Performance Allowance in the perspective of al-'Adl in the Indonesian Ministry of Religion, Gowa Regency. This type of research is a type of qualitative descriptive study with a phenomelogical approach that explains the phenomena and their meaning for individuals by conducting interviews with a number of individuals and the location of the study was conducted at the Indonesian Ministry of Religion, Gowa Regency. Sources of data obtained consisted of primary data sources of 12 informants, as well as secondary data. Data collection methods used are observation, interviews, and documentation. The results of this study indicate that the process of receiving performance allowances in the manner of payment and giving, addition, and reduction of performance allowances is in accordance with government regulations. In addition, the value of Al-'Adl is an imbalance in the receipt of performance benefits with employee performance which is assessed through employee performance appraisal. The value of Al-'Adl is that there is no equality in providing training opportunities and infrastructure for employees. The value of Al-'Adl is that there is a mismatch
\end{abstract}


in the receipt of performance allowances based on the time of payment, employee workload, and employee obligations.

Keywords: Performance, Allowances, imbalances, Al-'Adl.

\section{Introduction}

Law No. 43 of 1999 stipulates that Civil Servants are entitled to receive fair and appropriate salaries in accordance with their workload and responsibilities. Based on these regulations, the government issued a policy that is the receipt of performance benefits.

The provision of performance allowances is an inseparable part of government policy towards implementing bureaucratic reform and part of the government's commitment to realize clean government and good governance. According to the Ministry of Administrative Reform and Bureaucratic Reform, performance benefits are defined as a function of the success of implementing reforms on the basis of the performance achieved by an employee. Thus, because benefits are a form of appreciation for the submission and giving of all employee's performance to the organization, the organization provides rewards as a source of income for the employee concerned. Basically, the performance allowance can be a positive thing that is expected to stimulate the enthusiasm and motivation of every employee to work more effectively, and to be more active. ${ }^{1}$ Receiving this allowance makes it easier for employees to fulfill their

${ }^{1}$ See Ludi Wishnu Wardana dan Yuli Agustina, Tunjangan Kinerja Pegawai di Lingkungan Pemerintahan Kota Mojokerto, Jurnal PETA Vol 3 No 1, Januari 2018, p. 46-47. 
daily needs, thus avoiding KKN (Corruption, Collusion and Nepotism) behavior.

However, the practice of bribery, the practice of giving preferential treatment, and the appointment of families to work results in weak government bureaucracy, and the government is less able to empower existing potentials. While the government continues to try to raise the salaries of civil servants with a weak state bureaucracy. In the end, the President's criticism surfaced ${ }^{2}$ "The Waste Basket Bureaucracy", then the President's expression emerged, "that the government is really trying to increase the salaries of civil servants, but is it true that its performance, corruption, collusion, nepotism and discipline, if civil servants are paid tens of millions?"

According to Dahlstrom who conducted research on the application of the incentive / benefit system in four countries, namely: Sweden, Spain, Korea, and Japan, which explained that the system was needed to encourage the enthusiasm and motivation of employees in carrying out their duties and increasing work productivity. Through a fair and challenging incentive / allowance system, employees are encouraged to achieve certain work performance in order to get these benefits. ${ }^{3}$

${ }^{2}$ See Sedarmayanti, Manajemen Sumber Daya Manusia: Reformasi Birokrasi dan Manajemen Pegawai Negeri Sipil, (Bandung: PT Refika Aditama, 2011), p. 335.

${ }^{3}$ See Jusdin Puluhulawa, Penerapan Sistem Insentif Tunjangan Kinerja Daerah (TKD) untuk Meningkatkan Kinerja Pegawai di Provinsi Gorongtalo, Jurnal Aplikasi Manajemen (JAM) Vol 9 No 4 Juli 2011, p. 1292. 
The Secretary General of the Ministry of Religion of the Republic of Indonesia explicitly asked all employees of the Ministry of Religion who had been still a bit naughty both openly or secretly violating the Basic Values of the State Civil Apparatus according to Law Number 5 of 2014 must be obeyed including upholding the ideology of Pancasila, being loyal and maintaining the 1945 Constitution and legitimate government. It is advisable for such employees to carry out repentance, because if not heeded, strict sanctions will be applied. ${ }^{4}$

The direction given by the Secretary General of the Ministry of Religion of the Republic of Indonesia in the Ministry of Religion of South Sulawesi shows that the performance of employees is still needed to be improved both for the center and the regions, especially in the Ministry of Religion of Kab. and clean from the practices of corruption, collusion and nepotism.

Islam teaches people to care for others, caring among themselves can be shown in the company and / or bureaucracy by teaching the principles of justice and morality (morals) to fellow employees in providing rewards for services in Islam. Allah Almighty says in QS Al-Mãidah / 5: 8 as follows:

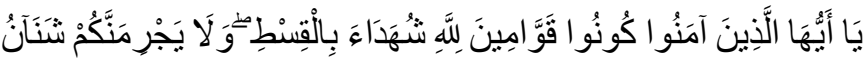

\section{Jadi}

${ }^{4}$ See Mawardy Siradj, Sekjen Kemenag RI: Korps ASN Harus https:// fajaronline.co.id/read/35332/sekjen-kemenag-ri-korps-asnharus-jadi-pusat-inovasi-pelavanan-publik diakses pada tanggal 2/10/2018 pukul 22.14, 2017 . 


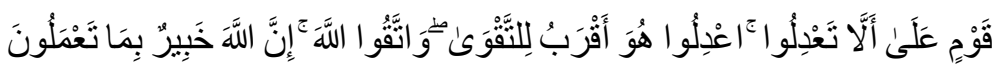
Translation:

Oh believers, be men who have always (Allah) upheld (the truth), a just witness. And don't ever hate your people, they encourage you to be unjust. Be fair, because justice is closer to piety. And fear Allah, for Allah knows best what you do..$^{5}$

The provision of benefits for employee performance that has been done must be designed in the form of justice, so that it can consider both employee contributions and the needs of employees. The value of justice does not contain elements of tyranny, exploitation of labor or elements of fraud, but must contain justice. Fair in providing benefits, is useful in meeting the needs of clothing, food and shelter for employees and has value.

\section{Research Methodology}

This type of research is a qualitative descriptive study. Qualitative research is a research method used in expressing problems in the working lives of government, private, community, youth, women's, sports, arts and cultural organizations, so that it can be used as a policy to be implemented for the common good.6

The approach used is the phenomelogy approach that

${ }^{5}$ See Kementerian Agama RI, Mushaf Al-Qur'an Terjemah, (Jakarta: al-Huda, 2002), p. 109.

'See Imam Gunawan, Metode Penelitian Kualitatif; Teori \& Praktik, (Jakarta: Bumi Aksara, 2016), p. 80. 
explains the phenomena and their meaning for individuals by conducting interviews with a number of individuals. The phenomenological approach seeks to let reality express itself naturally, through inducement questions. The research subjects were allowed to tell all kinds of dimensions of their experiences related to a phenomenon / event. Phenomenology studies assume that every individual experiences a phenomenon with all his consciousness.7 Data sources that will be used in this study are primary and secondary data sources. Primary data is data obtained from the first source either from individuals or individuals such as the results of interviews or the results of questionnaires that are usually done by researchers. The informants in this study are as follows:

Group of Informan

\begin{tabular}{|l|l|l|}
\hline No. & Group of Informan & Informan \\
\hline 1. & Authorized office & $\begin{array}{l}\text { - Head of the Indonesian } \\
\text { Ministry of Religion's Office, } \\
\text { Gowa Regency } \\
\text { - Head of Administration } \\
\text { Subdivision }\end{array}$ \\
\hline 2. & Structural officer & $\begin{array}{l}\text { - Head of Islamic Community } \\
\text { Guidance Section } \\
\text { - Section Chief Peny. Haji and }\end{array}$ \\
\hline
\end{tabular}

${ }^{7}$ See O Hasbiansyah, Pendekatan Fenomenologi: Pengantar Praktik Penelitian dalam Ilmu Sosial dan Komunikasi, Jurnal Mediator Vol 9 No 1, Juni 2008, p. 170. 


\begin{tabular}{|c|c|c|}
\hline & & $\begin{array}{l}\text { Umrah } \\
\text { - Head of KUA Kec Bajeng }\end{array}$ \\
\hline 3. & $\begin{array}{l}\text { Certain functional } \\
\text { employees }\end{array}$ & $\begin{array}{l}\text { - Staffing analyst } \\
\text { - Staff Development Staff } \\
\text { - extension agent } \\
\text { - teacher }\end{array}$ \\
\hline 4. & $\begin{array}{l}\text { General functional } \\
\text { staff }\end{array}$ & $\begin{array}{l}\text { Ministry of Religious Affairs, } \\
\text { Gowa }\end{array}$ \\
\hline
\end{tabular}

While secondary data is primary data that has been further processed and presented either by primary data collectors or by other parties, for example in the form of tables or diagrams. This secondary data is used by researchers for further processing. 8 The power collection methods used in this study are observation, interviews, and documentation. Researchers will use research instruments such as interview guides, observation guidelines, and checklists for interviews to be conducted, and recording devices.

The data processing technique used in this study is a qualitative technique that emphasizes more on the analysis of the inductive inference process and on the analysis of the dynamics of the relationship between observed phenomena using scientific logic, and the emphasis is on answering research questions through thinking and argumentative ways. Validity testing in qualitative research methods uses interval

${ }^{8}$ Husein Umar, Metode Penelitian Untuk Skripsi dan Tesis Bisnis/Oleh Husein Umar Ed Baru, Cet2, (Jakarta: PT RajaGrafindo Persada, 1999), h. 42 
validity in the aspect of truth value, in its application in terms of external validity, and reliability in the aspect of consistency, and objectivity in the naturalist aspect. Data and findings will be tested by means of a credibility test. The credibility test proves that what is observed is true, or in accordance with what actually exists or occurs, in order to obtain credible data, researchers use validation techniques.

\section{Findings and Discussion}

\section{The Process of Receiving Performance Allowances at the Indonesian Ministry of Religion, Gowa Regency}

\section{a. Procedure for Payment of Performance Allowances}

Implementation of procedures for payment of performance allowances is carried out in accordance with Regulation of the Minister of Finance of the Republic of Indonesia Number 80 / PMK.05 / 2017. In the performance payment payment phase, the staff and treasurer of the Indonesian Ministry of Religion in Gowa Regency play an important role in managing data and submitting payment documents to KPPN. This management requires collaboration between employees both structural and functional positions to collect daily performance reports and employee attendance lists in each section in accordance with the time agreed upon at the Indonesian Ministry of Religion in Gowa Regency.

Thus, the process of receiving performance allowances at the Ministry of Religion of the Republic of Indonesia in Gowa Regency is based on the Regulation of the Minister of Finance of the Republic of Indonesia Number 80 / PMK.05 / 2017 by recapitating two important factors in receiving performance allowances, namely the daily performance report and the print out of attendance on finger 
print first done then processed by PPK, PPSPM, treasurer, and KPPN.

\section{b. Granting, Adding and Reducing Performance Allowances}

Regulation of the Minister of Religion of the Republic of Indonesia Number 11 Year 2019 concerning the Granting of Employee Performance Allowances to the Ministry of Religion, Chapter II Article 2 states that performance benefits are given to employees every month. The amount of performance allowance is based on class position, the performance allowance considers the performance of the organization and individual performance. ${ }^{9}$

Then Article 3, namely the performance allowance is not given to employees who: ${ }^{10}$

1. Officers who do not have a specific department.

2. Employee who is temporarily suspended or disabled.

3. An employee who is dismissed from his or her organic position by being given a waiting period and has not been terminated as an employee.

4. Employees who are granted leave on national leave or on duty-free leave to prepare for retirement.

5. Officers at public service agencies who have been remunerated.

${ }^{9}$ Menteri Agama Republik Indonesia, Peraturan Menteri Agama Republik Indonesia Nomor 11 Tabun 2019 tentang Pemberian Tunjangan Kinerja Pegawai pada Kementerian Agama, Chapter II Verse 2.

${ }^{10}$ Menteri Agama Republik Indonesia, Peraturan Menteri Agama Republik Indonesia Nomor 11 Tabun 2019 tentang Pemberian Tunjangan Kinerja Pegawai pada Kementerian Agama, Chapter II Verse 3. 
The reduction of performance allowances is regulated in the Minister of Religion Regulation of the Republic of Indonesia Number 11 Year 2019 Granting Employee Performance Allowances to the Ministry of Religion, Chapter III, Article 8 which explains the reduction of performance allowances known to employees who: ${ }^{11}$

1. Without valid reasons:

a) Do not come to work, amounting to $3 \%$ for every 1 (one) day.

b) Being late for work, while the percentage is as follows:

\section{Table 4.5}

Percentage of Reduction in Employee Performance Allowances that is Late for Working

\begin{tabular}{|l|c|c|}
\hline $\begin{array}{l}\text { Delay } \\
\text { (D) }\end{array}$ & Long delay in coming to work & $\begin{array}{c}\text { Percentage } \\
\text { reduction }\end{array}$ \\
\hline D.1 & 1 minute to $<30$ minutes & $0.5 \%$ \\
\hline D.2 & 31 minutes to $<60$ minutes & $1 \%$ \\
\hline D.3 & 61 minutes to $<90$ minutes & $1.25 \%$ \\
\hline D.4 & $\begin{array}{c}>90 \text { minutes and / or do not fill in } \\
\text { the attendance list at work }\end{array}$ & $1.50 \%$ \\
\hline
\end{tabular}

Source: Peraturan Menteri Agama Republik Indonesia Nomor 11 Tahun 2019 Pemberian Tunjangan Kinerja Pegawai pada Kementerian Agama.

c) Going home earlier, the percentage is as follows:

\section{Table 4.6}

${ }^{11}$ Menteri Agama Republik Indonesia, Peraturan Menteri Agama Republik Indonesia Nomor 11 Tabun 2019 tentang Pemberian Tunjangan Kinerja Pegawai pada Kementerian Agama, Chapter III Verse 8. 


\section{Percentage of Reduction of Performance Allowances for Employees Returning Before Their Time}

\begin{tabular}{|c|c|c|}
\hline $\begin{array}{c}\text { Going Home } \\
\text { Earlier (GHE) }\end{array}$ & $\begin{array}{c}\text { Long Left Duty Before } \\
\text { Time }\end{array}$ & $\begin{array}{c}\text { Reduction } \\
\text { Percentage }\end{array}$ \\
\hline GHE.1 & 1 minute to $<30$ minutes & $0.5 \%$ \\
\hline GHE.2 & 31 minutes to $<60$ minutes & $1 \%$ \\
\hline GHE.3 & 61 minutes to $<90$ minutes & $1.25 \%$ \\
\hline GHE.4 & $\begin{array}{c}>90 \text { minutes and / or do } \\
\text { not fill in the attendance list } \\
\text { from work }\end{array}$ & $1.50 \%$ \\
\hline
\end{tabular}

Source: Peraturan Menteri Agama Republik Indonesia Nomor 11 Tahun 2019 Pemberian Tunjangan Kinerja Pegawai pada Kementerian Agama.

d) Employees who are not in their assignments (between when they come to work and when they leave work) without assignments or written permission from the direct supervisor, amounting to $2 \%$.

e) No partner attendance at work, $1.5 \%$ for every 1 (one) incident.

f) Do not do attendance at the time of returning home prematurely, at $1.5 \%$ for every 1 (one) time.

2. Known termination for temporary or deactivated, provided:

a) Employees who are temporarily terminated or deactivated due to exposure to or involved in a legal case and / or are undergoing a period of detention by the authorities, are 
subject to a $100 \%$ reduction in performance allowance starting from the stipulation of the temporary dismissal.

b) If based on a court decision that has permanent legal force, the employee is found not guilty then the performance allowance is paid back the following month.

Reduction of performance allowance is calculated cumulatively in 1 month at most by $100 \%$. Reduction of performance allowance is not applied if it has a valid reason and meets the procedural requirements for delivering a valid reason.

The data obtained can be seen that the recapitulation of the presence of the Civil Service show that there are some employees in the Ministry of Religious Affairs Gowa Regency get a reduction in performance benefits based on being late to work and go home prematurely. This is supported by the results of interviews with informants, as stated by Jamaris as follows:

A delay of one minute to half an hour, we have a reduction in performance allowances. Because we use a reduction system and a TL 1 to TL 4 system, as well as going home before time is very influential. Secondly, the more effective the work that they do. Because if he does not perform according to defined job descriptions based tupoksinya, it would seem the performance are reported later that he did not do what he should do. ${ }^{12}$

${ }^{12}$ Jamaris (45 Years), Head of Administrative Subdivision of the Ministry of Religion of the Republic of Indonesia Gowa Regency, Interview, Ministry of Religion of the Republic of Indonesia Gowa Regency, February 26, 2019. 
As for the Regulation of the Minister of Religious Affairs of the Republic of Indonesia Number 11 Year 2019 Provision Benefit Performance Officer at the Ministry of Religion, Chapter III, Article 15, namely a reduction in performance benefits apply to employees who receive the value of work performance in the current year under good value, as follows: ${ }^{13}$

1) Employees who receive performance in the current year value with value enough, in the next year to the help given its performance benefits reduction of $25 \%$ (twenty five percent) of the performance benefits it receives.

2) Employees are assigned the value of the performance in the current year with a value of less, the following year to the help given its performance benefits reduction of $50 \%$ (fifty percent) of the performance benefits it receives.

1) Pegawai yang mendapatkan nilai kinerja pada tahun berjalan dengan nilai buruk, pada tahun berikutnya kepada pegawai tersebut diberikan pengurangan tunjangan kinerja sebesar 75\% (tujuh puluh lima persen) dari tunjangan kinerja yang diterimanya.

Then Article 16 confirms that the addition of performance allowance is given $50 \%$ of the difference in performance allowance for the above class position for employees who get very good work performance scores. Additional performance allowances are given at the beginning of the following month. ${ }^{14}$

Based on the results of interviews with informants, as stated by Abdul Hafid regarding the reduction of

${ }^{13}$ Menteri Agama Republik Indonesia, Peraturan Menteri Agama Republik Indonesia Nomor 11 Tabun 2019 tentang Pemberian Tunjangan Kinerja Pegawai pada Kementerian Agama, Chapter III Verse 15.

${ }^{14}$ Menteri Agama Republik Indonesia, Peraturan Menteri Agama Republik Indonesia Nomor 11 Tabun 2019 tentang Pemberian Tunjangan Kinerja Pegawai pada Kementerian Agama, Chapter III verse 16. 
performance allowances based on employee performance values, namely:

In addition to getting a tukin reduction due to being late for work or not checking the lock, the employee also gets a reduction in the tukin if the performance score is below good, and getting an additional tukin if the score is very good. ${ }^{15}$

Job performance evaluation is a process of performance management series that starts from the preparation of the Employee Work Targets (SKP), the determination of benchmarks that include aspects of quantity, quality, time and cost of each activity of job assignment. ${ }^{16}$ As for the determination of benchmarks for civil servant work behavior, namely orientation, service, integrity, commitment, discipline, cooperation, and leadership. This is similar to the explanation by Abdul Hafid, which is as follows:

For employee quality, each employee fills in an assessment of work performance. Filling that there are targets that must be achieved, namely quality, quantity and time of completion of the task, then there is an assessment of employee behavior so far. Direct superiors must assess what is filled in the sheet is appropriate or not, so well direct superiors have an important role in directly assessing and supervising subordinates. ${ }^{17}$

${ }^{15}$ Abdul Hafid (Age 54) Head of Hajj and Umrah Ministry of RI Kab Gowa Religious Affairs, Interview, RI Kab Gowa Religious Ministry, 26 February 2019.

${ }^{16}$ Lena Satlita, Yanuardi dan Marita Ahdiyana, Penilaian Kinerja Pegawai di Pemerintah Kota Yogyakarta, Jurnal Kajian Ilmu Administrasi Negara Volume 3 Nomor 1 Tahun 2015, p. 47.

${ }^{17}$ Abdul Hafid (54 years) Head of Haj and Umrah Section of Ministry of Religious Affairs of GI Kab Gowa, Interview, Ministry of Religious Affairs of GI Kab Gowa, 26 February 2019. 
Thus, based on the results of documentation, observation and interviews it can be concluded that the granting, reduction and addition of performance allowances at the Ministry of Religion of the Republic of Indonesia Gowa Regency is based on the Minister of Religion Regulation No. 11 of 2019 concerning Provision of Employee Performance Allowances at the Ministry of Religion.

\section{Al-'Adl value with a balance in the Implementation of Performance Allowances in the Ministry of Religion of the Republic of Indonesia, Gowa Regency}

Al-'adl values are a concept that must be applied as a whole to aspects of life both social, political and economic and so forth. Al-adl (justice) describes the balance, comparison, harmony as represented in justice in terms of laws and granting rights to those entitled to. ${ }^{18}$ Thus, justice and fairness should be applied in all aspects of life, especially in the provision of benefits. Performance is a reference for fairness and worthiness in receiving the performance allowance.

Al-'adl value in the sense of balance that is the fulfillment of the benefits provided in accordance with the proportion of performance that has been produced, no less and no more. Suitability between work (both work time and ability of employees) and suitability of employee work with the amount of compensation received and time received. The results of research on the value of Al-'Adl with a balance in the implementation of performance allowances in the Ministry of Religion of the Republic of Gowa Regency analyzed in several ways, are as follows:

\section{Attendance of Officers}

${ }^{18}$ Armansyah Waliam, Upah Berkeadilan Ditinjau Dari Perspektif Islam, Jurnal Bisnis Vol 5 No 2, Desember 2017, p. 269 
Employee performance appraisal is the main factor to be able to measure employee performance, based on the results of attendance documentation obtained there are still some employees who have not been able to obey the work hours set in the Ministry of Religion of the Republic of Gowa Regency. The employee received a reprimand by the direct supervisor, As this was stated by Mustainah:

Work behavior that was lazy, there are some who often have activities outside and then he does not make a report, it is usually empty attendance list. We used to reprimand, but still in the form of verbal reprimands. ${ }^{19}$

Similar to what has been revealed by Jamaris:

There are already some who are reprimanded for employees who indeed they come and go home later want to checklock again and then come. Of course this greatly affects his work. Therefore, to prevent this, leadership control is very much needed, and secondly, I think it needs additional policies, even if it cannot add a checklock at rest and after a break, then all employees who leave the room for more than 2 hours must have the leadership knowledge.. ${ }^{20}$

The verbal reprimand in question is an oral reprimand from the direct superior, then if there is no change, an oral warning will be given from the office management. From the

${ }^{19}$ Mustainah (51 Years), Staffing Ministry of Religion RI Gowa Regency, Interview, Ministry of Religion RI Gowa Regency, March 4 2019.

${ }^{20}$ Jamaris (45 Years), Head of Administrative Subdivision of the Ministry of Religion of the Republic of Indonesia Gowa Regency, Interview, Ministry of Religion of the Republic of Indonesia Gowa Regency, February 26, 2019. 
results of observations made, for now the warning given to employees who violates work time is only verbal reprimand.

\section{Employee Daily Performance Access Report}

Reports on employee daily performance are different from the SKP (Employee Work Target) description which is described based on quantity, quality, time and cost. Whereas LCKH is elaborated based on activities, volume of activities and activity units as well as information on those activities. Each employee is required to report activities every month through a logbook recapitulation which is a requirement for disbursement of employee performance benefits.

The results of observations made there are problems associated with daily performance reports that many are still late in collecting the report. As this was stated by the Head of KUA Bajeng, Mr. Akbar Samad:

In daily reporting which is sometimes negligent in daily records so that many are overwhelmed that employees should have to make records every day, but until now it can still be handled properly. ${ }^{21}$

Based on the results of documentation, observation and interviews, it can be seen that some employees are still negligent in recording daily performance reports. It is also only handled by verbal reprimands from the direct supervisor and the Head of the Office, then the Head of the Office of the Ministry of Religion of the Republic of Indonesia, Gowa Regency determines the 5 th of the following month to be the limit for the collection of employee daily performance reports to be processed in order to get performance benefits.

${ }^{21}$ Akbar Samad (44), Head of the Rifles Ministry of Religious Affairs of GI Kab Gowa, Interview, Ministry of Religious Affairs of GI Kab Gowa, 21 February 2019. 


\section{Performance Appraisal of Employees}

Evaluation of employee work targets in the form of main duties and additional tasks and creativity as an element of supporting assessment. Evaluation of work targets, it can be seen that the realization of the quantity and quality of work has almost reached the expected target. The assessment is filled in by the employee concerned and checked by the direct supervisor, while in the assessment of additional tasks provided by the direct supervisor with a certificate of carrying out the additional tasks that are signed directly. The additional assignments are assessed based on the number of additional assignments not assessed based on the quality, quantity and time of completion of the task.

Evaluation of additional tasks in the assessment of work targets above, the percentage value of 1.00 which means that additional work has been done in 1 (one) year for 1 (one) to 3 (three) times, namely the head of the Hajj manasik guidance committee. Gowa, moderator in the activities of guiding the team leader and group leader, the committee for the departure and return of pilgrims, and the 73rd HAB committee of the Ministry of Religion of the Republic of Indonesia. Gowa While the percentage value of 3.00 which means that additional work has been carried out in 1 (one) year of 7 (seven) or more, namely the implementation of the flag ceremony and protocoller activities.

The results of observations obtained at the Ministry of Religion of the Republic of Gowa Regency are the employee's work targets to date have good categorization. This is as stated by Ms. Herlina: 
There are no employees who have SKP below good grades, so far thank God SKP all good employees. ${ }^{22}$

However, the assessment still lacks proper supervision so that it can lead to inaccurate, subjective and unprofessional judgments of superiors in assessing employee performance. Employee performance appraisal is carried out by the employee itself in filling in the assessment of employee work goals (SKP) and is carried out by the direct supervisor in filling in the assessment of employee work behavior, which can also be given input by fellow co-workers. But in essence, almost all assessments of work behavior are carried out by direct superiors who are the best position to supervise the work behavior of their subordinates.

Assessment of work behavior carried out by direct superiors is not based on objective principles, this is because not all direct superiors can properly monitor and supervise their subordinates in accordance with aspects of work behavior assessment that has been determined in their daily work. This was stated by Fahruny Syarifuddin:

There are some who entered the report that were not properly checked. Examination from direct superiors is still not good, right superiors should immediately see what is done by the employee itself and in accordance with what is reported, in accordance with the activities of the job assignment. ${ }^{23}$

Then shown by Ibrahim:

There must be an audit of results if indeed the results of his work have results so that it can be an assessment which then becomes a record that the work has been completed and

${ }^{22}$ Herlina (35 Years), Staffing Officer, Interview, Ministry of Religion of the Republic of Indonesia, Gowa Regency, March 4, 2019.

${ }^{23}$ Fahruny Syarifuddin (38 Years), Staff of the Indonesian Ministry of Religion, Gowa Regency, Interview, Ministry of Religion RI Gowa Regency, March 4, 2019. 
completed and is reasonable to get the value of what was done according to grade.

Based on the results of the interview, there is an injustice in the supervision of superiors given to employee appraisals. The need for the formation of an internal supervision team at the Ministry of Religion of the Republic of Gowa Regency can directly verify the daily performance reports and annual employee performance appraisals that are adjusted to the grade of each employee. The performance appraisal carried out every year is used to improve work performance in the following year, as a basis for decisions on employee placement, planning and career development of the employee concerned, as well as fair employment opportunities.

Positioning activities that are filled in employee performance reports that are not in accordance with employee work objectives will not be recapitulated at the end of the year. This indicates that the employee fills in the daily performance report with indifference and the direct supervisor who verifies the report simply ignores and does not ask the employee to make improvements.

Imposing sanctions for employees who are negligent in the collection of LCKH, arriving late and returning before their time just getting verbal reprimands. This suggests that a boss and leader are less assertive in responding to the behavior of employees who are less committed and less disciplined, the only sanctions given are verbal reprimands which are mild sanctions and most likely the employee will continue to repeat his mistakes again. This is in accordance with the results of an interview by Mr. Abdul Hafid as Head of the Hajj and Umrah Organizer Section:

Remain in the knowledge, skills and abilities such as cooperation and competence, but not yet maximized. This is because the supervision of the leadership 
above has not been continued, so that other employees do whatever they want.

Thus, the assessment of employee work performance in the Ministry of Religion of the Republic of Gowa Regency is still considered to be less balanced because in the assessment of employee work targets (SKP) it can be assessed to have been objective and well-measured by comparing targets and realization of job assignment activities. However, for the assessment of employee work behavior, there is still a subjective element due to the limited ability of direct superiors to assess, the personal relationship between subordinates and direct superiors, as well as the uncertainty of direct superiors and leaders in disciplining employees, so that employee performance appraisal is considered inaccurate and balanced in accordance with the amount of performance benefits received by employees.

Al-'Adl Value with the Similarities in the Implementation of Performance Allowances in the Ministry of Religion of the Republic of Indonesia, Gowa Regency

In the value of this justice that is there is no difference and priority among fellow creatures before God Almighty. Because God is the master of everything. Abbad al-Akkad said that a good equality is justice in which there is no element of tyranny (lā tazlimuna walā tuzlamuna). Therefore, justice is to equate the same two forms in accordance with the limits of equality and the similarity of the conditions of the two, or distinguish between two different things according to the boundaries of the difference and the linkage of conditions between the two. ${ }^{24}$

${ }^{24}$ Armansyah Waliam, Upah Berkeadilan Ditinjau Dari Perspektif Islam, Jurnal Bisnis Vol 5 No 2, Desember 2017, p. 269. 
As for the results of this study, the value of al-'adl in the performance allowance system on the meaning of equality or non-discrimination is as follows:

1. Equality in Opportunities for Developing Competencies: PNS Education and Training Program.

One way that can be done in improving employee performance is through developing employee quality in the form of expertise, abilities and skills by conducting education and training programs. Therefore, a comprehensive and continuous effort by the government is needed to improve the development and development of education and training programs (Diklat). Based on the results of the interview with the Head of Administration Mr. Jamaris who explained that:

The training is not comprehensive for every employee, it happens because there is a limited training budget at the Office of the Ministry of Religion of the Republic of Indonesia, South Sulawesi. Our standard 2 years they have to train, but in fact the number of our employees is large while the quota is small, ultimately not all can. ${ }^{25}$

This indicates that the problems experienced in education and training programs (training) are the availability of a budget where the budget for employee expenditure activities is limited so that employee education and training activities are prioritized on pre-service training activities, leadership training, functional training and technical training.

The education and training carried out in the Indonesian Ministry of Religion in Gowa Regency still relies heavily on the policy of training the Ministry of Religion of the Republic of Indonesia in the South Sulawesi Region and

${ }^{25}$ Jamaris (45 Years), Head of Administrative Subdivision of the Ministry of Religion of the Republic of Indonesia Gowa Regency, Interview, Ministry of Religion of the Republic of Indonesia Gowa Regency, February 26, 2019. 
the Makassar Religious Training Center. Then to determine the employees who will follow the training is still based on the decision of the personnel analyst, but the determination is prioritized for employees who have never participated in training and in accordance with employee competencies. This is in line with the results of the interview with the Head of Administration Mr. Jamaris who explained that:

We can only send according to request, thank God we are priorities that have not. Each class that is asked for training is only 2 (two) in one year, whereas we have 143 noncivil servant extension workers. ${ }^{26}$

The determination of participants in this training, can be seen that the selection process such as seniority and employees who have never followed the same training for 5 consecutive years has not been implemented properly. Some senior employees who have never carried out education and training are not called to attend the training. This is based on the results of an interview by Mrs. Syamsinar as the Tompobulu extension agent of the Indonesian Ministry of Religion, Gowa Regency:

For the training provided, only a few of them did not even participate in the training until the contract was completed. $^{27}$

This is in line with the explanation of Mr. Abdul Hafid, as the Section Head of Peny. Hajj and Umrah Ministry of Religion of the Republic of Indonesia, Gowa Regency:

For those who do not get training, it is actually a pity, it should all be given training to improve human resources

${ }^{26}$ Jamaris (45 Years), Head of Administrative Subdivision of the Ministry of Religion of the Republic of Indonesia Gowa Regency, Interview, Ministry of Religion of the Republic of Indonesia Gowa Regency, February 26, 2019.

${ }^{27}$ Syamsinar (56 years old), Muslim Religious Extension of Tompobulu District, Interview, RI Kab Gowa Religious Ministry, February 20, 2019. 
such as the private sector. If it can be seen here, the training has not been evenly distributed because sometimes there are those who participate and there are no or absolutely dominant ones. ${ }^{28}$

Thus, based on the results of interviews and the results of documentation and observations that have been made, it can be concluded that the education and training program (training) carried out is still based on training invitations from the Office of the Ministry of Religion of the South Sulawesi Region and the Makassar Religious Training Center. And the selection process for determining which employees will take part in training is still unfair and directed, so that the equality in providing opportunities to participate in education and training programs (training and education) in the Ministry of Religion of the Republic of Indonesia Gowa is still there obstacles that are expected to provide equal opportunities between one employee and employees who other.

2. Equality in Providing Facilities and Infrastructure.

The meaning of justice in the economy is equality in opportunities and facilities, and recognizes the difference in ability to take advantage of the opportunities and facilities provided. Therefore, there must not be someone who does not have the opportunity to develop the ability to enable him to carry out one of the obligations, and also no one who does not get the means to be used to achieve this opportunity. ${ }^{29}$ Facilities and infrastructure also become obstacles for employees in maximizing their performance, this is similar to the explanation by Mustainah:

${ }^{28}$ Abdul Hafid (54 years) Head of Haj and Umrah Section of Ministry of Religious Affairs of GI Kab Gowa, Interview, Ministry of Religious Affairs of GI Kab Gowa, 26 February 2019.

${ }^{29}$ Armansyah Waliam, Upah Berkeadilan Ditinjau Dari Perspektif Islam, Jurnal Bisnis Vol 5 No 2, Desember 2017, h. 270. 
Facilities and management in his office can also be a barrier and psychology in his office can also. For transportation can be a barrier especially for employees in the highlands, Gowa regency there are 18 districts in which 9 districts for the highlands and there are some constraints that are constrained such as soil texture that is different from the city. Employees get a salary but for transportation money, the state is not strong enough to pay it. ${ }^{30}$

Facilities in carrying out work tasks such as computers, air conditioners, vehicles and so on are still an obstacle so as to affect the performance of employees in the work environment. Especially for employees who are centered on high altitude work, they have dangerous distance, network and road barriers. The Indonesian Ministry of Religion must pay more attention to employees in supporting performance improvement.

Thus, equality in the opportunity to develop competence in the form of education and training programs (employee training) and the provision of facilities and infrastructure is still considered not able to meet the value of Al-'Adl. only stagnant in that position alone, the selection process for the determination of employees who will take part in training must be carried out an analysis of employee needs which can then be known which employees need to be prioritized in providing training opportunities. Provision of facilities and infrastructure is expected to be distributed equally, so that between one employee there is no jealousy over these facilities and infrastructure and can support the improvement of employee performance in the Ministry of Religion of the Republic of Indonesia Gowa Regency.

${ }^{30}$ Mustainah (51 Years), Staffing Ministry of Religion RI Gowa Regency, Interview, Ministry of Religion RI Gowa Regency, March 4 2019. 


\section{Value of Al-'Adl with Attention to Individual Rights and Giving Those Rights to Every Owner}

Included in the principle of justice is fulfilling the rights of their owners. On the contrary, Islam firmly does not commit wrongdoing with one another. By not giving rewards after doing work, being reduced, or postponed is a form of tyranny. Allah SWT. said in QS Āli 'Imrān / 3: 30 which is as follows: ${ }^{31}$

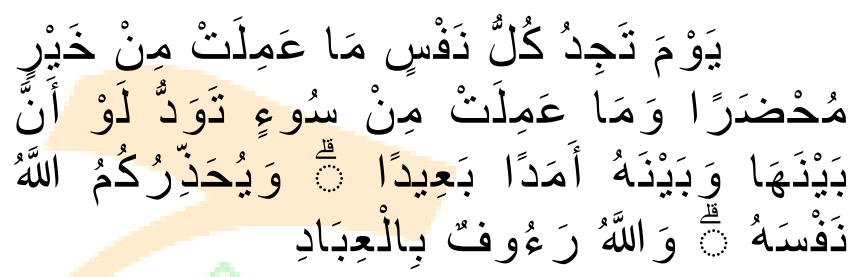

\section{Translation:}

"In the day when every man shall find his own good, and the evil that he hath done; very kind to his servants. "

In the research results, the value of Al-'adl in fulfilling employee and office rights is as follows:

1. Receipt of Performance Allowances in Accordance with Payment Period.

The constraints that result in late payment of performance allowances, namely:

a) Late monthly LCKH (Daily Performance Achievement Report) summary

b) Late summarizing employee attendance lists

c) Inaccurate annual budget planning

d) There are changes in employee positions

${ }^{31}$ Kementerian Agama RI, Mushaf Al-Qur'an Terjemah, (Jakarta: Al-Huda, 2002), h. 55. 
This is similar to the presentation by Mustainah:

The calculation is usually the payment of the performance allowance there must be a JFU SK for general functional officials, so usually the decree is not yet issued. For delays in depositing LCKH also includes delays, meaning that this is like $18 \mathrm{KUA}$, when one KUA is late then the whole payment is automatically too late. The next problem is the budget proposal, such as 2019, which was proposed in MarchApril, while in the current year usually there are those who move / enter the Ministry of Religion so that it increases or there is an increase in grade, so it increases again. That's where the budget is lacking, but that doesn't mean it isn't paid. That's usually a revised term. ${ }^{32}$

The existence of these constraints, giving injustice to other employees, where employees who are late collecting LCKH sheets and attendance lists, this will affect other employees. Staffing will summarize reports according to each section, most employees who are often late in collecting LCKH, namely KUA employees in the form of head and extension workers who are placed in the highlands have a great distance to the Office of the Ministry of Religion of the Republic of Gowa Regency and so on. This is as stated by Mujahid:

The two biggest problems are the first, namely the non-uniform LCKH (daily work performance report) coming per district and the second the attendance list per district is slow, some are fast and some are not. Usually caused by a finger print system that is damaged or has a blackout, the reason is obvious like this. ${ }^{33}$

${ }^{32}$ Mustainah (51 Years), Staffing Ministry of Religion RI Gowa Regency, Interview, Ministry of Religion RI Gowa Regency, March 4 2019.

${ }^{33}$ Mujahid Dahlan (47 years), Head of the Islamic Community Guidance Section of the Ministry of Religion of the Republic of Indonesia Gowa Regency, Interview, Ministry of Religion of the Republic of Indonesia Gowa Regency, March 4, 2019. 
Employees who are late in collecting LCKH and attendance list of these employees no later than the 5th, if the collection exceeds that date then the performance allowance can be merged in the following month. Then the late payment of this performance allowance can take up to three months. But for the whole, this payment takes place every month as long as these obstacles can be overcome.

Then, the payment of performance allowances for certified and uncertified civil servant teachers that should be given to teachers to date has still not been paid. While the government has promised payment of performance benefits in 2019, performance benefits are provided from 2015 to 2019. This was stated by staffing staff, Ms. Herlina:

Tukin (charged performance) for certified and uncertified teachers has not been paid to date. This year should have been paid. ${ }^{34}$

Similar to the portrayal of one of the teachers, Mrs. Marlina:

Yes, the tukin has not been paid to date, even though it has been paid from 2015-2019. We were only asked to collect the files to the staffing, but at this time it has not been disbursed. ${ }^{35}$

Thus, it can be seen that the receipt of performance allowances in accordance with the time to date is still experiencing many obstacles both from the employees themselves and from the manager who are still inaccurate and the teacher's performance allowances which until now have still not been paid.

${ }^{34}$ Herlina (35 Years), Staffing Officer, Interview, Ministry of Religion of the Republic of Indonesia, Gowa Regency, March 4, 2019.

${ }^{35}$ Marlina (45 years old), MTs Teacher N Lecture, Interview, RI Kab Gowa Religious Ministry, 6 September 2019. 


\section{Acceptance of Performance Allowances In Accordance With Employee Workloads}

Each employee has an analysis of the position and workload to be responsible. In carrying out their duties and responsibilities, some employees, especially functional employees such as extension workers and headmasters, have quite challenging tasks and responsibilities. This is because, must travel a considerable distance and lack of transportation which is an obstacle that must be faced. As explained by Syamsinar:

Not suitable for religious extension agents in the highlands, for the workload between one region to another requires effort while we are not given facilities to facilitate our workload. ${ }^{36}$

However, the Ministry of Religion of the Republic of Indonesia receives $70 \%$ performance allowances, this is due to the existence of regulations on the evaluation of each Ministry / and Institution based on performance for 3 consecutive years to achieve $100 \%$ performance allowance. Thus, the workload given to each employee is not in accordance with the performance allowance received, which is $70 \%$ of the performance allowance. This is consistent with what was expressed by Mr. Ibrahim:

For the next increase in performance allowance, we really need it, because we are institutions that deal directly with the community with a burden that is not easy while only $70 \%$ while there are other ministries that are $100 \%{ }^{37}$

Thus, the workload received by each employee is complained because it is not in accordance with the

${ }^{36}$ Syamsinar (56 years old), Muslim Religious Extension of Tompobulu District, Interview, RI Kab Gowa Religious Ministry, February 20, 2019.

${ }^{37}$ Ibrahim (37 Years), Staff of the Indonesian Ministry of Religion Gowa Regency, Interview, Ministry of Religion of the Republic of Indonesia Gowa Regency, March 4, 2019. 
performance allowance received. Performance benefits are very meaningful for every employee, not only to help in meeting the needs of life but also to motivate every employee to carry out their duties and responsibilities. Thus, the achievement of the value of al-'Adl is the fulfillment of the rights and obligations of each employee, so there is no discrimination between one party and another party.

\section{Receiving Performance allowances in accordance with Employee Obligations}

Being fair is closely related to the rights that a person has must be treated fairly. Rights and obligations are also related to the mandate, while the mandate must be delivered to those entitled to receive it. Therefore, law based on trust must be applied fairly, without being followed by hatred and other negative traits. In another sense it requires a balance between rights and obligations, between the rights obtained by a person and the obligations that must be fulfilled. ${ }^{38}$

Based on the results of observations, there are some employees who cannot obey the provisions of disciplinary regulations in the form of work time in the Ministry of Religion of the Republic of Indonesia in Gowa Regency with late coming to work and returning home prematurely, to the attitudes and behavior of employees that cannot be exemplary in him, this in accordance with a statement by Mr. Abdul Hafid, as the Head of the Peny Section. Hajj and Umrah:

There are still some employees who do finger prints and come home and come in a few hours later. ${ }^{39}$

${ }^{38}$ Armansyah Waliam, Upah Berkeadilan Ditinjau Dari Perspektif Islam, Jurnal Bisnis dan Manajemen Islam Vol 5 No 2, Desember 2017, p. 270.

${ }^{39}$ Abdul Hafid (54 years) Head of Haj and Umrah Section of Ministry of Religious Affairs of GI Kab Gowa, Interview, Ministry of Religious Affairs of GI Kab Gowa, 26 February 2019. 
Then, the negligent attitude experienced by employees in reporting the daily performance of employees which has been explained by Mr. Akbar, as the Head of KUA Kec Bajeng Gowa Regency:

In daily reporting which is sometimes negligent in daily records so many are overwhelmed that employees should have to make records every day. ${ }^{40}$

The attitude and behavior of the employee is due to the sluggishness of the employee and cannot understand the duties and responsibilities assigned to him so that the employee neglects to perform them. This is in line with the presentation by Mr Akbar, Head of KUA District Bajeng Kab Gowa District:

First, personal laziness then does not understand the execution of tasks that have been imposed on them. This is most dominant, when they realize it all, I think the performance of the employees will be good. ${ }^{41}$

Based on the results of the study, it can be concluded that employees at the Ministry of Religion of the Republic of Indonesia in Gowa Regency for receiving performance allowances are not in accordance with the obligations of employees in carrying out their duties and responsibilities. Employee attitudes and behavior cannot be made an example to other employees and the public who have a sense of responsibility to provide the best service, behave and act well and correctly and uphold the values and code of ethics as a state civil apparatus.

Officials at the RI Kab Gowa religious ministry are expected to give high motivation to the staff either from the

${ }^{40} \mathrm{Akbar}$ Samad (44), Head of the Rifles Ministry of Religious Affairs of GI Kab Gowa, Interview, Ministry of Religious Affairs of GI Kab Gowa, 21 February 2019.

${ }^{41}$ Akbar Samad (44), Head of the Rifles Ministry of Religious Affairs of GI Kab Gowa, Interview, Ministry of Religious Affairs of GI Kab Gowa, 21 February 2019. 
office leader or from the employee itself so that the employee can work more diligently in carrying out the duties imposed on him. Then, strict supervision of the sectional head and office leader is required of the employee regarding the discipline and execution of the employee's duties, giving more stringent punishment so that the employee does not repeat the mistake, as well as the rewards.

Thus based on this study, it can be seen that the Ministry of Religious Affairs Minister GI Kab Gowa in fulfilling the individual rights of the employee and giving the owner such a receipt of performance allowance has not been compliant with the payment time, workload, and duties of the employee where there are few constraints of both the employee himself and the Ministry of Religious Affairs of GI Kab Gowa so that improvements are needed that can provide justice in accepting performance allowance based on time, workload and employee obligations.

\section{Conclusion}

The conclusion that can be drawn is that First, the process of receiving performance allowances at the Ministry of Religion of the Republic of Gowa, based on the results of the study shows that the payment of performance allowances is in accordance with the Regulation of the Minister of Finance of the Republic of Indonesia Number 80 / PMK.05 / 2017 concerning Procedures for Paying Employee Performance Allowances to State Ministry / Institution. Then, the application of granting, adding and reducing performance allowances is in accordance with the Regulation of the Minister of Religion of the Republic of Indonesia Number 11 Year 2019 concerning Granting Employee Performance Allowances has been implemented.

Second, the value of Al-'Adl with the balance in the receipt of performance allowances at the Ministry of Religion of Gowa Regency, based on the results of the study shows the 
receipt of performance allowances with employee performance, which is still considered less balanced because in the assessment of employee work performance namely employee work objectives (SKP) can considered to have been objective and well-measured by the comparison of targets and the realization of job assignment activities, while the assessment of employee work behavior still contained a subjective element.

Third, the value of Al-'Adl with the similarity in receiving performance allowances at the Ministry of Religion in Gowa Regency, based on the results of the study shows that there are still some constraints, namely lack of budget, limited training participants who will represent each office, and constraints of facilities and infrastructure that have not adequate. And fourth, the value of Al-'Adl with attention to the rights of individuals and giving these rights to each owner in the receipt of performance allowances at the Ministry of Religion of Gowa Regency, based on the results of research shows there are still some obstacles to the receipt of performance allowances that are not according to time payment, not in accordance with the workload given to employees, and not in accordance with employee obligations.

\section{REFERENCES}

Gunawan, Imam. Metode Penelitian Kualitatif; Teori \& Praktik. Jakarta: Bumi Aksara, 2016.

Hasbiansyah, O. Pendekatan Fenomenologi: Pengantar Praktik Penelitian dalam Ilmu Sosial dan Komunikasi. Jurnal Mediator Vol 9 No 1. Juni 2008.

Kementerian Agama RI. Mushaf Al-Qur'an Terjemah. Jakarta: al-Huda, 2002. 
Menteri Agama Republik Indonesia. Peraturan Menteri Agama Republik Indonesia Nomor 11 Tabun 2019 tentang Pemberian Tunjangan Kinerja Pegawai pada Kementerian Agama.

Puluhulawa, Jusdin. Penerapan Sistem Insentif Tunjangan Kinerja Daerah (TKD) untuk Meningkatkan Kinerja Pegawai di Provinsi Gorongtalo. Jurnal Aplikasi Manajemen (JAM) Vol 9 No 4 Juli 2011.

Satlita, Lena, Yanuardi dan Marita Ahdiyana. Penilaian Kinerja Pegawai di Pemerintah Kota Yogyakarta. Jurnal Kajian Ilmu Administrasi Negara Volume 3 Nomor 1 Tahun 2015.

Sedarmayanti. Manajemen Sumber Daya Manusia: Reformasi Birokrasi dan Manajemen Pegawai Negeri Sipil. Bandung: PT Refika Aditama, 2011.

Siradj, Mawardy. Sekjen Kemenag RI: Korps ASN Harus Jadi Pusat Inovasi Pelayanan Publik, https://fajaronline.co.id/read/35332/sekjenkemenag-ri-korps-asn-harus-jadi-pusat-inovasipelayanan-publik diakses pada tanggal 2/10/2018 pukul 22.14. Tahun 2017.

Umar, Husein. Metode Penelitian Untuk Skripsi dan Tesis Bisnis/Oleh Husein Umar Ed Baru. Cet2. Jakarta: PT RajaGrafindo Persada, 1999.

Waliam, Armansyah. Upah Berkeadilan Ditinjau Dari Perspektif Islam. Jurnal Bisnis Vol 5 No 2. Desember 2017.

Wardana, Ludi Wishnu dan Yuli Agustina. Tunjangan Kinerja Pegawai di Lingkungan Pemerintahan Kota Mojokerto. Jurnal PETA Vol 3 No 1. Januari 2018. 